\title{
Allelopathic Effect of Powdered Russian Knapweed (Acroptilon repens L.) on the Growth Parameters of Redroot Amaranth (Amaranthus retroflexus L.)
}

\author{
Alireza PIRZAD ${ }^{1,2 *}$, Mousa JAMALI ${ }^{3}$, Mohammad Amin ZAREH ${ }^{3}$, Fahime SHOKRANI ${ }^{3}$ \\ ${ }^{1}$ Institute of Biotechnology, Urmia University, Department of Medicinal and Industrial \\ Plants, Urmia, Iran; alirezapirzad@yahoo.com (" corresponding author) \\ ${ }^{2}$ Urmia University, Faculty of Agriculture, Department of Agronomy, Urmia, Iran \\ ${ }^{3}$ Payamenoor University of West Azerbaijan-Nagadeh, Faculty of Agriculture, Department of Agronomy, Iran
}

\begin{abstract}
To evaluate probable allelopathic effect of different parts of Russian knapweed (Acroptilon repens L.) on the growth of redroot amaranth (Amaranthus retroflexus L.) seedling, a factorial experiment was conducted based on randomized complete block design with three replications at the Faculty of Agriculture, Urmia University in 2012 (Iran). In this experiment, treatments were different parts of Russian knapweed (aerial part, flower and root) in different amounts (1, 2, 3 and $4 \mathrm{~g} / \mathrm{pot}$ ). Pots included $300 \mathrm{~g}$ of soil. Results showed the significant effect of Russian knapweed plant parts on the seedling emergence percent, root length, ratio of root/shoot length, seedling length, seedling fresh weight, and the significant effect of plant material amounts on the seedling emergence percent, seedling fresh weight and seedling dry weight. Interaction effect between plant material type and amount on the shoot length, root length, ratio of root/shoot length, seedling length was significant, too. The longest shoot $(3.51 \mathrm{~cm})$, root $(1.75 \mathrm{~cm})$, the highest ratio of root $/$ shoot length $(0.49)$ and seedling length $(5.26 \mathrm{~cm})$ belonged to control treatment. The highest seedling emergence percent of Amaranthus retroflexus (34.73\%) and seedling fresh weight $(0.176 \mathrm{~g})$ were occurred at pots treated by Russian knapweed aerial part. The lowest seedling emergence percent $(21.94 \%)$ and seedling fresh weight $(0.111 \mathrm{~g})$ were obtained from application of Acroptilon repens powdered root. The maximum seedling dry $(0.0126 \mathrm{~g})$ and fresh $(0.177 \mathrm{~g})$ weight of Amaranthus retroflexus were obtained from control treatment.
\end{abstract}

Keywords: Acroptilon repens, Allelopathy, Amaranthus retroflexus, plant parts, seedling

\section{Introduction}

Redroot amaranth (Amaranthus retroflexus L.) is a serious destructive weed which distributed worldwide, especially in farmland, orchards, gardens, the roadside and wasteland. It is so hard to control due to its extremely strong flexibility and large amount of seed. Redroot amaranth can seriously affect the growth of crops and pollute crop seeds, bringing great loss to agricultural production (Costea et al., 2004; Li et al., 2004). Amaranthus retroflexus is a summer annual invasive plant, widely distributed in Mediterranean and European area commonly found in cultivated lands (D’Abrosca et al., 2006).

Acroptilon repens (L.) DC (Russian knapweed; fomerly Centaurea repens), a perennial herbaceous plant belonging to the family Asteraceae, is an exotic invasive plant in North America and has been suspected to be allelopathic (Fletcher and Renney, 1963). Several natural products from this plant have negative effects on other organisms. Phytochemicals from Russian knapweed are harmful to other plants (Stermitz et al., 2003).

Its highly competitive nature and broad ecological adaptability make it a persistent weed problem in North America (Goslee et al., 2001). Allelopathy interactions are primarily based on the ability of certain plant species to produce secondary chemical compounds, that exert some sort of biological effects on other organisms, many of which are still unknown (Waller, 2004). Through delayed germination, lowered seed germination rate and inhibited seedling growth, reduced root-shoot ratio, the treatments lowered dry matter. The inhibitory effects were increased with increasing concentrations. Prolonged germination, delayed emergence and reduced biomass of the roots would have serious negative effect on the competition of plants for resources such as light, water and nutrients (Turk and Tawaha, 2003). Sun and Ho (2005) reported that antioxidant activities in many plants material primarily originate from their phenolic content, indicating a significant positive relationship between total phenolic content and antioxidant activity.

Based on our knowledge, there are no reports on the allelopathic effect of Russian knapweed, especially different parts of this plant, on the germination and seedling growth of redroot amaranth. Then, the main objective of this study is to evaluate probable allelopathic effect of powdered of aerial parts, root and flower of Acroptilon repens on the germination and seedling growth of Amaranthus retroflexus. 


\section{Material and methods}

To evaluate probable allelopathic effect of powdered originated from different parts of Russian knapweed (Acroptilon repens L.) on the growth of Amaranthus retroflexus, a factorial experiment was conducted based on randomized complete block design with three replications at the greenhouse condition at the Faculty of Agriculture, Urmia University with latitude of $37.53^{\circ} \mathrm{N}, 45.08^{\circ} \mathrm{E}$ and $1320 \mathrm{~m}$ above sea in 2012. Russian knapweed were collected freshly and dried at room temperature $\left(22-25^{\circ} \mathrm{C}\right)$ in dark condition for 7 days.

The dried material was chopped into $2 \mathrm{~cm}$ with an electric cutter. Treatments were different powdered (aerial part, flower and root) of Russian knapweed in varying amounts (0, 1, 2, 3 and $4 \mathrm{~g} / \mathrm{pot}$ ). Seeds of Amaranthus retroflexus were placed in pot and different powder amounts of each treatment were added to the bed (pots). Pots were filled by $300 \mathrm{~g}$ soil containing a silty clay soil, $\mathrm{pH} 7.15$. The emerged seedlings were recorded intervals day for a period of 14 days to obtain emergence percent (\%). The following measurements were recorded on five repetitive plants in each treatment per replication: root length $(\mathrm{cm})$, shoot length $(\mathrm{cm})$, seedling length $(\mathrm{cm})$ and root/shoot length.

\section{Statistical analysis}

Analysis of variance (ANOVA) on data was performed using the general linear model (GLM) procedure in the SAS software (SAS Institute Inc., 2000). The StudentNeuman Keul's test (SNK) was applied to compare treatment means using the MSTATC software package.

\section{Result and discussion}

Results of analysis of variance (ANOVA) showed the significant effect of different amounts of Russian knapweed on the emergence percent and seedling fresh weight, and significant effect of plant parts on the emergence percent, seedling fresh weight and seedling dry weight $(p \leq 0.01)$. Interaction effect between different amounts and plant parts on the shoot length, root length and ratio of root/shoot length $(p \leq 0.01)$, seedling length $(p \leq 0.05)$ was significant, too (Tab. 1).

Means comparison revealed that the highest emergence percent of Amaranthus retroflexus (24.84\%) was occurred at $3 \mathrm{~g} /$ pot powdered of Acroptilon repens as same as by 4 $\mathrm{g} /$ pot. The maximum seedling dry $(0.0126 \mathrm{~g})$ and fresh $(0.177 \mathrm{~g})$ weights of Amaranthus retroflexus were obtained from control treatment (without Acroptilon repens). The lowest seedling fresh weight $(0.107 \mathrm{~g})$ and dry $(0.008 \mathrm{~g})$ were observed in $4 \mathrm{~g} /$ pot of Amaranthus retroflexus (Tab. 2).

The highest emergence percent of Amaranthus retroflexus $(34.73 \%)$ and seedling fresh weight $(0.176 \mathrm{~g})$ were occurred at pots treated by Russian knapweed aerial part. The lowest emergence percent (21.94\%) and seedling fresh weight $(0.111 \mathrm{~g})$ were obtained from application of Acroptilon repens root (Tab. 3 ).

The longest shoot of Amaranthus retroflexus $(3.51 \mathrm{~cm})$ belonged to control treatment. The shortest shoot of $\mathrm{Am}$ aranthus retroflexus $(1.58 \mathrm{~cm})$ belonged to application of $4 \mathrm{~g} /$ pot of Acroptilon repens aerial part, as same as $4 \mathrm{~g} / \mathrm{pot}$ powdered flower of Acroptilon repens. The longest root of

Tab. 1. Analysis of variance of different amounts and plant parts of Russian knapweed (Acroptilon repens L.) on the seedling emergence and growth of Amaranthus retroflexus $\mathrm{L}$

\begin{tabular}{|c|c|c|c|c|c|c|c|c|}
\hline \multirow[b]{2}{*}{ Source of Variation } & \multicolumn{8}{|c|}{ Means Squares (MS) } \\
\hline & df & $\begin{array}{c}\text { Emergence } \\
\text { percent }\end{array}$ & $\begin{array}{l}\text { Shoot } \\
\text { length }\end{array}$ & Root length & $\begin{array}{c}\text { Root/Shoot } \\
\text { length }\end{array}$ & $\begin{array}{l}\text { Seedling } \\
\text { length }\end{array}$ & $\begin{array}{c}\text { Seedling } \\
\text { fresh weight }\end{array}$ & $\begin{array}{l}\text { Seedling } \\
\text { dry weight }\end{array}$ \\
\hline replication & 4 & $23.82^{*}$ & $2.05^{*}$ & $0.19^{\prime \prime}$ & $0.065^{*}$ & 1.16 & $0.0003^{*}$ & 0.00001 \\
\hline powder amounts (A) & 2 & $37.83^{*}$ & $25.88^{* *}$ & $3.27^{\prime \prime}$ & $0.080^{*}$ & $18.93^{*}$ & 0.0016 & $0.00003^{*}$ \\
\hline plant parts (B) & 4 & $4.77^{\circ}$ & $1.32^{* *}$ & $0.05^{*}$ & $0.018^{*}$ & $0.13^{\circ}$ & 0.0001 & 0.00001 \\
\hline$A \times B$ & 8 & 9.69 & $0.77^{*}$ & $0.019 "$ & $0.059^{*}$ & $0.042^{\circ}$ & 0.00009 & 0.000001 \\
\hline Error & 56 & 5.32 & $0.21^{*}$ & $0.21^{*}$ & $0.003 "$ & $0.065^{\circ}$ & 0.00008 & 0.000002 \\
\hline Coefficient of variatio & (\%) & 9.79 & 5.67 & 13.34 & 13.89 & 7.018 & 7.76 & 13.45 \\
\hline
\end{tabular}

and "Significant at $p \leq 0.05, p \leq 0.01$, respectively; df, degree of freedom

Tab. 2. Means comparison of seedling emergence, seedling dry and fresh weight of Amaranthus retroflexus under varying amounts of Russian knapweed plant material

\begin{tabular}{cccc}
\hline Plant material amounts (g/pot) & Seedling dry weight $(\mathrm{g})$ & Seedling fresh weight $(\mathrm{g})$ & Emergence percent $(\%)$ \\
\hline 0 & $0.0126 \mathrm{a}$ & $0.177 \mathrm{a}$ & $24.5 \mathrm{a}$ \\
1 & $0.011 \mathrm{ab}$ & $0.133 \mathrm{~b}$ & $21.83 \mathrm{~b}$ \\
2 & $0.010 \mathrm{ab}$ & $0.123 \mathrm{c}$ & $21.83 \mathrm{~b}$ \\
3 & $0.010 \mathrm{ab}$ & $0.119 \mathrm{c}$ & $24.84 \mathrm{a}$ \\
4 & $0.008 \mathrm{~b}$ & $0.107 \mathrm{~d}$ & $24.82 \mathrm{a}$ \\
\hline
\end{tabular}

The same letters in each column show the non-significant differences at $p \leq 0.05$ 
362

Tab. 3. Means comparison of seedling fresh weight and emergence percent of Amaranthus retroflexus L. affected by plant material parts of Acroptilon repens L.

\begin{tabular}{ccc}
\hline Plant material parts & $\begin{array}{c}\text { Seedling fresh } \\
\text { weight }(\mathrm{g})\end{array}$ & $\begin{array}{c}\text { Emergence } \\
\text { percent }(\%)\end{array}$ \\
\hline aerial part & $0.176 \mathrm{a}$ & $34.73 \mathrm{a}$ \\
root & $0.111 \mathrm{c}$ & $21.94 \mathrm{c}$ \\
flower & $0.122 \mathrm{~b}$ & $23.02 \mathrm{~b}$ \\
\hline
\end{tabular}

The same letters in each column show the non-significant differences at $p \leq 0.05$

Amaranthus retroflexus $(1.75 \mathrm{~cm})$ and ratio of root/shoot length (0.49) belonged to control treatment. The shortest root of amaranth $(0.44 \mathrm{~cm})$ was obtained from $4 \mathrm{~g} / \mathrm{pot}$ powdered root of Acroptilon repens, as same as $4 \mathrm{~g} / \mathrm{pot}$ of aerial part and flower of Acroptilon repens. The lowest ratio of root/shoot length (0.18) belonged to $4 \mathrm{~g} /$ pot of root powder obtained from Acroptilon repens. The maximum seedling length $(5.26 \mathrm{~cm})$ was obtained from control treatment, while the minimum seedling length $(2.17$ $\mathrm{cm}$ ) belonged to $4 \mathrm{~g} /$ pot of aerial part of Acroptilon repens (Tab. 4).

It release early in the season could affect other species at susceptible life stages (e.g., germinating seeds and young seedlings) (Weir et al., 2003). Russian knapweed (Acroptilon repens) secretes a phytotoxic flavonoid, 7.8-benzoflavone. This chemical was identified under soil-free conditions and caused toxicity in other species at $100 \mathrm{mg} \mathrm{ml}^{-1}$ (Stermitz et al., 2003).

Extract from different allelopathic plant parts showed significant differences in phytotoxicity to wheat seedling. At the all concentrations, the leaf extracts caused the greatest reduction in hypocotyl length when compared with other part extracts. The mixture of all extracts significantly reduced hypocotyl length of all concentrations when compared with the control (Turk and Tawaha, 2002). Inhibition of seed germination of crop plants was reported also due to disturbance in the activities of peroxidase, alphaamylase and acid phosphates (Alam and Islam, 2002).

In addition to temporal and seasonal variation in allelochemical production, differences may exist among genotypes, populations, or plants with differing ages. Age has been shown to affect allelopathic potential in Pinus halepensis (Fernandez et al., 2006). Abiotic and biotic factors differ with location and these may have strong influences on the production of allelopathic compounds (Einhellig, 1999). Körner and Nicklish (2002) found that the allelopathic algal growth inhibition was dependent on biomass of Myriophyllum spicatum. In our study, the allelopathic effects varied with the initial algal concentrations since the weights of submerged plants were fixed. Many of the phytotoxic substances suspected of causing germination and growth inhibition have been identified from plant tissues and soils (Whittaker and Feeny, 1977).

Pirzad et al. (2010) reported that effects of water extracts of sage and white worm wood on germination and seedling growth of purslane, the maximum fresh and dry seedling weight of purslane were obtained from untreated control. Delayed in germination of seeds can have osmotic effects on the rate of water absorption, delayed at the beginning of germination and especially cell elongation (Chon et al., 2005).

\section{Conclusions}

Our results indicated the greatest reduction of seedling emergence and growth indices of Amaranthus retroflexus in higher amounts of Russian Knapweed powdered root

Tab. 4. Means comparison of root length and shoot length, seedling length and ratio of root/shoot length of Amaranthus retroflexus L. under varying amounts of powdered dried parts of Acroptilon repens L.

\begin{tabular}{|c|c|c|c|c|c|}
\hline Plant material parts & $\begin{array}{c}\text { Plant (Acroptilon) material } \\
\text { amounts (g/pot) }\end{array}$ & $\begin{array}{l}\text { Seedling length } \\
(\mathrm{cm})\end{array}$ & $\begin{array}{c}\text { Root/Shoot } \\
\text { length }\end{array}$ & Root length $(\mathrm{cm})$ & $\begin{array}{l}\text { Shoot length } \\
(\mathrm{cm})\end{array}$ \\
\hline \multirow{5}{*}{ aerial part } & 0 & $5.26 \mathrm{a}$ & $0.49 \mathrm{a}$ & $1.75 \mathrm{a}$ & $3.51 \mathrm{a}$ \\
\hline & 1 & $3.86 \mathrm{c}$ & $0.42 \mathrm{abc}$ & $1.15 \mathrm{ab}$ & $2.71 \mathrm{abc}$ \\
\hline & 2 & $3.31 \mathrm{~d}$ & $0.48 \mathrm{ab}$ & $1.07 \mathrm{ab}$ & $2.23 \mathrm{bcd}$ \\
\hline & 3 & $2.60 \mathrm{e}$ & $0.42 \mathrm{abc}$ & $0.77 \mathrm{ab}$ & $1.82 \mathrm{~cd}$ \\
\hline & 4 & $2.17 \mathrm{f}$ & $0.37 \mathrm{abc}$ & $0.59 \mathrm{~b}$ & $1.58 \mathrm{~d}$ \\
\hline \multirow{5}{*}{ root } & 0 & $5.26 \mathrm{a}$ & $0.49 \mathrm{a}$ & $1.75 \mathrm{a}$ & $3.51 \mathrm{a}$ \\
\hline & 1 & $4.32 b$ & $0.49 a$ & $1.39 \mathrm{ab}$ & $2.93 \mathrm{ab}$ \\
\hline & 2 & $3.66 \mathrm{c}$ & $0.34 \mathrm{ab}$ & $0.93 \mathrm{ab}$ & $2.72 \mathrm{abc}$ \\
\hline & 3 & $3.20 \mathrm{~d}$ & $0.29 \mathrm{~cd}$ & $0.72 b$ & $2.47 \mathrm{bcd}$ \\
\hline & 4 & $2.76 \mathrm{e}$ & $0.18 \mathrm{~d}$ & $0.44 \mathrm{~b}$ & $2.23 \mathrm{bcd}$ \\
\hline \multirow{5}{*}{ flower } & 0 & $5.26 \mathrm{a}$ & $0.49 a$ & $1.75 \mathrm{a}$ & $3.51 \mathrm{a}$ \\
\hline & 1 & $4.23 b$ & $0.47 \mathrm{ab}$ & $1.36 \mathrm{ab}$ & $2.87 \mathrm{ab}$ \\
\hline & 2 & $3.89 \mathrm{c}$ & $0.43 \mathrm{abc}$ & $1.15 \mathrm{ab}$ & $2.65 \mathrm{abc}$ \\
\hline & 3 & $3.33 \mathrm{~d}$ & $0.41 \mathrm{abc}$ & $1.10 \mathrm{ab}$ & $2.22 \mathrm{bcd}$ \\
\hline & 4 & $2.43 \mathrm{ef}$ & $0.39 \mathrm{abc}$ & $0.69 \mathrm{~b}$ & $1.73 \mathrm{~d}$ \\
\hline
\end{tabular}

The same letters in each column show the non-significant differences at $p \leq 0.05$ 
materials followed by flowers material. The aerial parts of Russian Knapweed (Acroptilon repens L.) had a little effect on growth of amaranth, so the highest seedling emergence and growth was observed in this treatment.

\section{References}

Alam SM, Islam EU (2002). Effect of aqueous extract of Leaf, stem and root of nettleleaf goosefoot and $\mathrm{NaCl}$ on germination and seedling growth of rice. Pak J Sci Tech 1(2):47-52.

Costea M, Weaver SE, Tardif FJ (2004). The biology of canadian weeds, Amaranthus retroflexus L., A. powellii, S. Watson and $A$. hybridus L. Can J Plant Sci 84(2):631-668.

Chon S, Jang HG, Kim DK, Kim YM, Boo HO, Kim YJ (2005). Aellopathic potential in lettuce (Lactuca sativa L.) plants. Sci Hortic Amsterdam 106:309-317.

D’Abrosca B, De Maria P, Della Greca M, Fiorentino A, Golino A, Izzo A (2006). Monaco P Tetrahedron 62:640-646.

Einhellig FA (1999). An integrated view of allelochemicals amid multiple stresses, 479-494 p. In: Inderjit Dakshini KMM, Foy CL (Eds.). Principles and Practices in Plant Ecology: Allelochemical Interactions. CRC Press LLC, Boca Raton, FL.

Fernandez C, Lelong B, Vila B, Mevy JP, Robles C, Greff S, Dupouyet S, Bousquet-Melou A (2006). Potential allelopathic effect of Pinus halepensis in the secondary succession: an experimental approach. Chemoecol 16:97-105.

Fletcher RA, Renney AJ (1963). A growth inhibitor found in Centaurea spp. Can J Plant Sci 43:475-481.

Goslee SC, Peters DPC, Beck KG (2001). Modelling invasive weeds in grasslands: the role of allelopathy in Acroptilon repens invasion. Ecol Modelling 139:31-45.

Körner S, Nicklisch A (2002). Allelopathic growth inhibition of selected phytoplankton species by submerged macrophytes. J Phycol 38:862-871.
363

Li XJ, Zhang HJ, Ni HW (2004). Review on the biological characters and control of redroot pigweed (Amaranthus retroflexus). Pesticide Sci Admin 25(3):13-16.

Pirzad AR, Ghasemian V, Darvishzadeh R, Sedghi M, hassani A, Onofri A (2010). Allelopathy of sage and white wormwood on purslane germination and seedling growth. Not Sci Biol 2(3):91-95.

SAS Institute (2000). SAS User's Guide Version 8. SAS Institute, Cary, NC.

Sun T, Ho CT (2005). Antioxidant activities of buckwheat extracts. Food Chemistry 90(4):743-749.

Stermitz FR, Bais HP, Foderaro TA, Vivanco JM (2003). 7.8Benzoflavone: a phytotoxin from root exudates of invasive Russian knapweed. Phytochem 64:493-497.

Turk MA, Tawaha AM (2002). Inhibitory effects of aqueous extracts of black mustard on germination and growth of lentil. Pak J Agronom 1(1):28-30.

Turk MA, Tawaha AM (2003). Allelopathic effect of black mustard (Brassica nigra $\mathrm{L})$ on germination and growth of wild oat (Avena fatua L.). Crop Prot 22(4):673-677.

Waller GR (2004). Introduction-reality and future of allelopathy, 1-12 p. In: Macias FA, Galindo JCG, Molinillo JMG, Culter HG (Eds.). Allelopathy, Chemistry and Mode of Action of Allelochemicals. CRC Press, New York, USA.

Weir TL, Bais HP, Vivanco JM (2003). Intraspecific and interspecific interactions mediated by a phytotoxin, (-)-catechin, secreted by the roots of Centaurea maculosa (Spotted knapweed). J Chem Ecol 29:2397-2412.

Whittaker DC, Feeny PP (1977). Allelochemicals. chemical interactions between species. Sci 171:757-770. 